\title{
A THEORETICAL APPROACH INTO TOURISM, IMMIGRATION AND MULTICULTURALISM: THE CASE OF SOUTH AFRICA
}

\author{
Unathi Sonwabile HENAMA* \\ Tshwane University of Technology, Department of Tourism Management, Pretoria, \\ South Africa, e-mail: HenamaUS@tut.ac.za \\ Lwazi APLENI \\ Walter Sisulu University, Department of Tourism, Hospitality \& Sport Management, \\ East London, South Africa, e-mail: lapleni@wsu.ac.za
}

\begin{abstract}
Citation: Henama, U.S., \& Apleni, L. (2018). A THEORETICAL APPROACH INTO TOURISM, IMMIGRATION AND MULTICULTURALISM: THE CASE OF SOUTH AFRICA. GeoJournal of Tourism and Geosites, 23(3), 772-779. https://doi.org/10.30892/gtg.23313-327
\end{abstract}

\begin{abstract}
The article explores tourism migration within a South African context, focusing on migration and tourism circulation. Tourism and migration are interlinked with globalisation. Almost all countries have jumped on the tourism bandwagon as a result of the positive economic impacts such as labour-intensive jobs, balance of payments, attracter of foreign exchange and the taxation of non-residents. Tourism has been adopted in the economic development policies and a separate Ministry of Tourism has been created, because tourism required dedicated attention. The literature review adds to the paucity of academic scrutiny of the link between tourism and multiculturalism in South Africa. The in-depth literature review analyses various sources of secondary data, to provide an authoritative understanding of the literature and draw conclusions for the academic audience. The in-depth literature review of secondary data which used the meta-analytical methodology to investigate, and critically analyse the link between tourism and multiculturalism within a Southern African context. The interpretation of the literature resulted in the crafting of essential realities about the interface between tourism and multiculturalism which has received scant academic analysis in South Africa.
\end{abstract}

Keywords: Robben Island, migration, domestic tourism, Cathcart, Goshen village, Muslim tourism.

\section{INTRODUCTION}

Unemployment, poverty and inequality are the stubborn challenges facing South Africa. Creating labour-absorbing economic growth has been the major challenge facing the post-apartheid state. Job shedding has been the perennial reality, which has created a

\footnotetext{
* Corresponding author
} 
poverty problem as a result of unemployment. The decline in mining's share of GDP has negatively affected the economic prospects of South Africa. The decline in mining production has created widespread unemployment and it is accepted that when mining sneezes, the South African economy catches a cold. Tourism mitigated the decline of mining's contribution to economic growth and jobs. After years of isolation, South Africa has emerged as an attractive industry destination striving to position itself as a major player in this high-growth, global industry that has been identified in a South African perspective as a pro-poor empowerment asset of our young democracy" (Thornton, 2009: 9). Tourism is internationally recognised as one of the world's fastest-growing industries.

\section{RESEARCH METHODOLOGY}

The research method was a literature review. "Conducting a literature review is a means of demonstrating an author's knowledge about a particular field of study, including vocabulary, theories, key variables and phenomena" Randolph (2009: 2). The literature review depends on secondary data for analysis. Johnston (2014) noted that secondary data analysis is analysis of data that was collected by someone else for another primary purpose.

\section{DEVELOPMENTAL BENEFITS OF TOURISM}

The growth of tourism has caught the attention of almost all countries, which sought to benefit from the positive developmental impacts of tourism. According to the World Tourism Organisation the number of travellers has increased from 25 million in 1950 to 806 million in 2005 (Carolin et al., 2015). Tourism, according to the World Travel and Tourism Council, accounts for $9.3 \%$ of the GDP and $9.8 \%$ or approximately 1.5 million jobs in South Africa, and is expected to rise to about 2.5 million or $13.2 \%$ of the total number of jobs in the country in 2027 (World Travel and Tourism Council, 2017). The sustained growth of tourism has made it an attractive sector to diversity and catalyse national economies. Steyn and Spencer (2011) stated that tourism is the world's biggest industry, growing at compound rates of about $4 \%$ per annum. United Nations World Tourism Organisation (2018) noted that international tourist arrivals grew by a remarkable $7 \%$ in 2017 to reach 1,322 million, and it's expected to continue in 2018 at a rate between $4 \%-5 \%$. The arrival of tourists at a destination area increases business activity, and the consumption of goods and services.

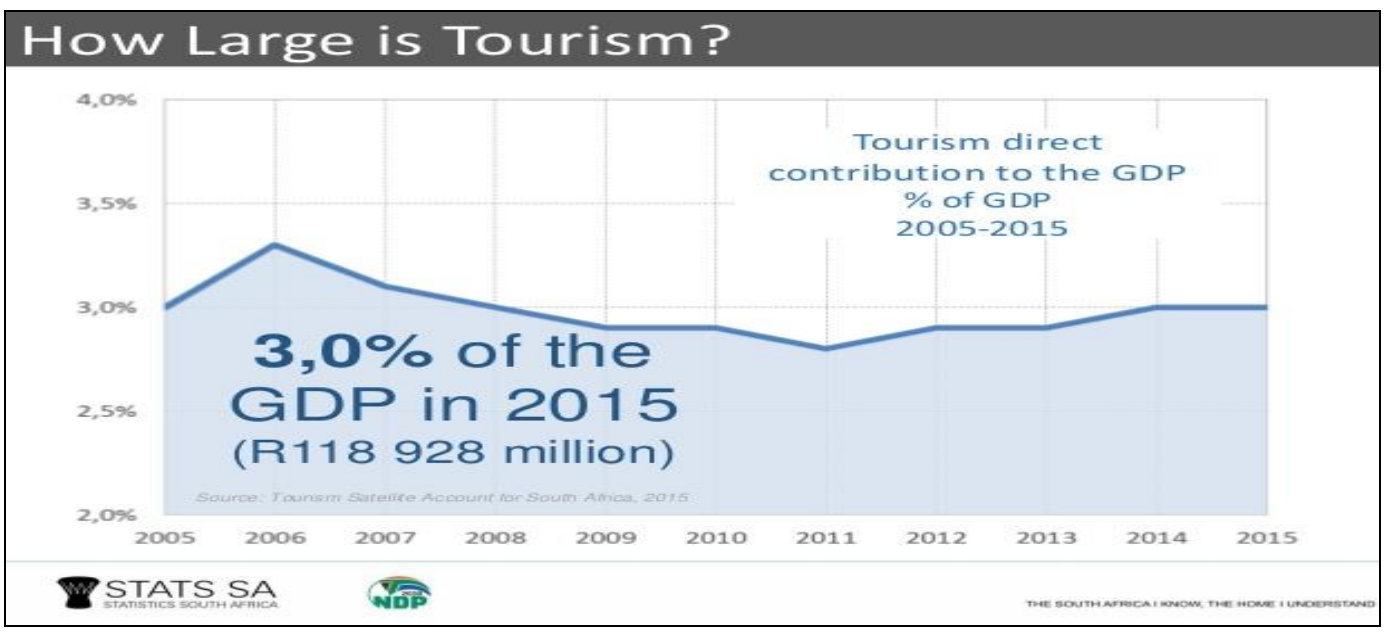

Figure 1. How large is Tourism in South Africa Source: Statistics South Africa (2018) 
Tourism is used as a form of economic diversification, from declining sectors such as mining, manufacturing and agriculture. In South Africa, tourism is regarded as the "new gold". Apleni et al., (2017) noted that tourism in South Africa has grown to become a leading sector that creates jobs in the country. South African tourism has grown in leaps and bounds since 1994 when South Africa held its first democratic elections. Henama and Sifolo (2017) noted that tourism had been identified as an engine for the South African economy. Tourism's annual growth rate has always surpassed the GDP growth of the South African economy for the past 20 years. Tourism contributes 3\% of the GDP in South Africa as noted by Statistics South Africa (2018). Sifolo \& Henama (2017) noted that governments can increase tax coffers by taxing non-citizens. These taxes can be used to fund infrastructure, as the fragile tax base of developing countries is increased. "Tourist development will bring about improvements to the local infrastructure, services and facilities that will benefit both residents and tourists. It may also stimulate the protection of local natural resources that are often the attraction of the developing destination" (Wall \& Mathieson, 2006: 84).

Tourism benefits the destination area, as the infrastructure that is created for tourists, is also shared with the locals. The development of roads, airports and better policing to cater for tourists, benefits the locals, which means that tourism improves the Quality-of-Life of the community. "The tourism industry is supposed to increase the standard of living of locals. Quality -of-Life of the host community must be improved by tourism employment and supply chain opportunities that will ensure that the benefits are retained in the local economy" (Henama \& Sifolo, 2017a). The growth of middle-class communities around the world means that tourism growth will be robust. The utilisation of tourism has been adopted as a form of lifestyle in many developed nations, and increasingly in developing nations. "Tourism has become part of a lifestyle" (Honkanen \& Mustonen, 2007: 43). According to Blichfeldt (2007), a family's annual vacation may also act as an institution such as family, school and religion. The growth of international travel, has also seen the growth of international citizenry, where people may have multiple homes as a result of globalisation. Globalisation has benefited tourism consumption, located within the dominant consumer culture. The increasing diversity of tourists has forced tourism destinations to adapt. The growth of Chinese tourists and millennials present opportunities for countries that actively adapt to cater for these markets. The inherent nature of service transactions as well as the growing competitiveness of destinations and businesses in particular, require foreign skills to be a necessity (Aitken \& Hall, 2010). Multiculturalism arises as a government's philosophical and political response to civilization develops.

It promotes different cultures and a specific orientation toward a culturally different population. This position advocates the inclusion of distinct cultural, ethnic and religious, with equal status, rights and opportunities because every culture and race makes a substantial contribution to its society. Henama and Sifolo (2017a) noted the growth of tourism at a destination area may lead towards an inward migration of tourists and labour to that local area. The inward migration of labour includes the unemployed and the skilled who come into the destination area as expatriate staff. Henama and Sifolo (2017a: 56) noted that "The tourism industry continues to follow a global trend of hiring foreign illegal undocumented labour, in spite of the high levels of unemployment that exists in South Africa." The use of foreign labour limits the developmental benefits of tourism at a destination area. Sifolo and Henama (2017) noted that tourism has the responsibility to improve the standard of living and quality-of-life for the host community.

\section{DOMESTIC TOURISM AND SECOND HOME OWNERSHIP}

According to the Department of Tourism (2013: 8), "Research has shown that domestic tourism tends to be the main sustainability factor for most successful 
destinations. Therefore, by 2020, the National Tourism Sector Strategy aims to increase the domestic tourism GDP by 60\% of tourism's overall contribution to the GDP, compared to the 2009 baseline of $52 \%$. Domestic tourism remains the most robust form of tourism for a destination, characterised by geographical spread when compared to international tourism. According to Visser and Hoogendoorn (2015: 118), "During the past ten years, it has become quite clear that, in the case of South Africa, second home tourism is not exclusive to the White, the wealthy, the mobile and the educated. Because of the social engineering policies of the apartheid regime, migration has stayed an important part of everyday life for many poor or middle-income people." "From 1948 onwards, Black South Africans were effectively stripped off of their citizenship making them legally citizens of the ten ethnically-based and nominally self-governing Bantustans or tribal homelands" Rogerson (2014: 23). The establishment of self-governing Bantustans created the migrant labour system which institutionalised migration between the Bantustans, as the centres of labour, and the urban centres of commerce, as places of employment. Gauteng and the urban centres of Cape Town, the greater Durban and the greater Port Elizabeth area have been the main centres of employment.

This has therefore meant that migrant labourers would have two homes, a home in the urban centres of employment and a home in the Bantustans, which meant that the face of Black tourism has been dominated by visiting friends and relatives. Rogerson (2017) noted that Blacks are over-represented in the tourism market that is identified as, "Visiting Friends and Relatives" (VFR). "Another aspect of Black domestic tourism was expanding in the form of a little recognised or 'hidden' informal sector of travel. This informal economy of domestic tourism was represented by movements out from the country's urban areas to rural 'second homes' which were situated in areas created as labour reservoirs under South Africa's political economy of cheap labour” Rogerson (2015: 124).

South Africa has experienced a migration of wealthy individuals as well as the migration of the poor and job seekers to the Western Cape. Property24 (2017) noted the Western Cape as the retirement mecca of South Africa. Heystek (2017) noted the average house price in the Western Cape is now 40\% more expensive than average prices in Gauteng and other parts of the country. The migration of the relatively affluent individual is called "lifestyle migration". The Western Cape, which is the epicentre of the tourism economy of South Africa, has seen the emergence of second homes and inward migration where tourists acquire property in the Western Cape. This has increased the cost of accommodation in the Western Cape, and, has led to gentrification challenges, where locals are being priced out of the market. The gentrification of the Western Cape has seen an inward migration of people from other countries that have increasingly changed the demographic character of the Western Cape. This means over time, the Western Cape will benefit from VFR inward migration, which may predominantly be White, considering that the VFR market in South Africa presently is predominantly Black.

\section{ROBBEN ISLAND AND MUSLIM RESISTANCE}

The arrival of the Europeans that conquered South Africa has led to the arrival of slaves from other parts of the world, and as a result led to the development of a resident Muslim population. Blickford-Smith (2009) noted that in the $16^{\text {th }}$ century, the Table Bay area was a place of barter between the Peninsula's Khoisan inhabitants and the crews of ships between Europe and the East Indies. "To many travellers of the sea route to the East Indies, Robben Island became a major source of fresh supplies in those early years" (Lubbe 1987: 50). The decision of the Dutch East Indian Company (DEIC) in 1652 to establish a refreshment station was the means to an end to achieve colonialism in the southern part of Africa. The establishment of the refreshment station has also been 
associated with the establishment of Robben Island as a place of incarceration. The Dutch exiled leaders from East Asia, which included Java. According to Lubbe (1987), several Muslim noblemen were exiled to Robben Island. These included Doumano of Termano (1738), Daing Mangeman (1749), and Sheik Madura (1742). Lubbe (1987) noted that a shrine (or karamat) has been erected on Robben Island in honour of Sheikh Madura as a silent reminder of his fierce opposition to Dutch colonialism.

According to Blickford-Smith (2009), British took control over the Cape from the Dutch which led to the freeing of slaves in the 1830s. The Bo-Kaap area in Cape Town, with its colourful buildings, became the residential area of the freed slaves of which the majority were Muslim. "Despite landing at the Cape from Africa, India, Sri Lanka, Malaysia and elsewhere in Asia, the people of this community became known as 'Cape Malays' and the area, the 'Malay Quarter' Cape Town. (2017: 1). Today, the Bo-Kaap Museum showcases the local Islamic culture and heritage as well as the history of the freed slaves. The arrival of Muslims in the Cape was imperative for the development of a resident Muslim population in South Africa. According to Zamani-Farahani and Eid (2015), the Organisation of Islamic Cooperation (OIC) which was established in 1969 and which represents the majority of Muslim States, is the second largest intergovernmental organisation after the United Nations. In research conducted by MasterCardCrescentRanking (2016), South Africa is the fourth most popular non-OIC destination for Muslims in the MasterCard-CrescentRating Global Muslim Travel Index (GMTI).

Hamza et al., (2012) noted that Muslim tourism is tourism that is mainly targeting people with Islamic beliefs. "Halal tourism refers to the provision of a tourism product and service that meets the needs of Muslim travellers to facilitate worship and dietary requirements that conform to Islamic teachings" (Alkhulayfi et al., 2015: 10). As a consequence of the arrival of Muslims in the Cape Peninsula, they went about building places of prayer and worship. According to Peterson (2017), the Masjidul-Jamiah in Kalk Bay was established in 1898 and is a hundred-year-old heritage site. South African Tourism (2017) noted that the most visited kramat is that of Sheikh Yusuf of Mcassar, the first Muslim to read from the Holy Koran in South Africa and who is regarded as the father of local Islam. "Robben Island is currently South Africa's most famous cultural tourism attraction, located in a 30 minute ferry trip from the coast of Cape Town, South Africa. In 1999, Robben Island was declared one of South Africa's first three World Heritage sites" (Shackley, 2001: 356). Today, Robben Island is associated with full blown mass tourism, as it is one of the major tourism destinations in South Africa. The critical number of Muslims has meant that South African cities have become attracted to increase their share of the growing Muslim travel market. News24 (2014) noted that statistics reveal that Cape Town is seen as an ideal holiday destination for Muslim tourists because of the Muslim history of Cape Town.

According to Zamani-Farahani and Eid (2015: 10), "Following the $11^{\text {th }}$ of September 2001, Muslims preferred to travel to and within destinations deemed friendlier. On the other hand, some Muslim countries have also benefited from in-tourism." Haines (2017:3) noted that "after 9/11, the US Congress passed the USA Patriot Act, which amended US immigration laws and impacted the passage of travellers by introducing inperson interviews for visa applications and biometric procedures (fingerprints and photos) at borders. This had a huge impact on America's tourism industry. The election of Donald Trump as the President of the United States of America, is following September 11, the second most significant impactor on Muslim tourism. In January 2017, Mr Trump signed an execution order that restricted immigration from the following Muslim majority countries: Iran, Iraq, Sudan, Syria, Libya, Somalia and Yemen. The decree was not a surprise as Mr Trump has been vocal during his campaign to assume office that this 
would be one of the first things he will do when he moves into the Oval Office at the White House. According to The Economist (2017), the decree could have the impact of putting off global travellers from visiting the USA. Haines (2017) noted that the travel ban was unprecedented; history was hinting that it could have far-reaching implications for tourism in the US. "Trump has presented his decree as a way to protect the United States from Islamist militants, but it has been condemned by a growing list of foreign leaders and draws protests from thousands in American cities" Reuters (2017: 2).

The USA is a major tourist destination, in the bigger scheme of things; a decline in the desire to travel to the USA would benefit other international destinations. On the flipside, the travel ban could also limit USA outbound tourism, which would be devastating for the world tourism economy. The USA has one of the major outbound tourism markets in the world. The closure of American airspace immediately after the September 11 terrorist attack, not only had a negative impact on the global tourism trade, as America is a major and profitable aviation route for many airlines, but also robbed the world of American tourism expenditure. As noted by Reuters (2017), Asian countries that are majority Muslim territories such as Malaysia, have taken advantage of the Trump travel ban, by focusing on Muslim tourism. South Africa must also take advantage of its Muslim accessibility, and actively pursue the Halal tourism market to diversify the tourism market segments of South Africa as a destination. Muslim tourism is expected to grow and South Africa must exploit the growth of this sector. This implies that there must be constant engagement with the private sector to ensure that it caters for Muslim tourists whose needs and preferences may be different.

\section{SCHOENSTATT "MOTHER SHRINE OF AFRICA" CATHCART}

Cathcart is a peri-rural town located along the N6 highway, 50 kilometres from Queenstown, in the Eastern Cape. It was a small military post established during the Frontier War, between the Xhosa native population and the British, the colonial power. The area was originally occupied by the San and the Xhosas. According to South African History Online (2017), the area was called Windvogelberg, after a San chief. The mountains around Cathcart are called the Windvogelberg Mountains. In 1877, AmaNgqika led a rebellion against the British, the colonial power governing the Cape Colony (South African History Online, 2017). German missionaries arrived in the Cathcart area, and spread the Christian faith amongst the native population. According to Frisk (2000), Kentenich sought to spread the Schoenstatt faith by sending nuns to South Africa, Uruguay, Argentina, Brazil and Chile in the 1930s. The nuns were expected to build replicas of the Schoenstatt shrine in Germany.

Schoenstatt (2017) noted that the Cathcart shrine was the first Schoenstatt shrine built in Africa in 1949 and it is called the "Mother Shrine of Africa". It is a direct replica of the Vallender shrine (Urheiligtum) near Koblenz in the Rhine province. There are only nine of their kind in South Africa. The Schoenstatt shrines remain sites of pilgrimage, where pilgrims receive the three graces of feeling at home, of being spiritually transformed and of apostolic zeal. Astell and Peters (2014) affirm that Schoenstatt is a movement that was founded and established by Joseph Kentenich in Germany in 1914 with the outbreak of World War I. The arrival of German missionaries in Cathcart, led to the development of a Schoenstatt shrine, and today there are nine in South Africa. The legacy of the San is reflected in Bushmen paintings in several caves around the village of Goshen, outside Cathcart. The Frontier War between the Xhosa and the English led to the dispossession of land by the Xhosas, which is reflected in today's reality where land ownership in South Africa remains skewed. The shrine is an opportunity to create religious pilgrimages that can drive tourism consumption in the Cathcart area. This can be an opportunity to attract German tourists to the Cathcart area, considering that Germany is one of the top three inbound 
international source markets for South Africa. Social media in addition to traditional marketing platforms can be used to market the religious and pilgrimage experience that is "off-the-beaten track". Marketing outlays must be sustained to ensure tourism consumption demand, increases the introduction of "new money" as tourists spend money in the local economy of Cathcart. There is ample opportunity to use religious and pilgrimage tourism associated with Schoenstatt shrine, as an economic growth point for the local economy.

\section{DISCUSSIONS AND CONCLUSIONS}

Multiculturalism is a character of South Africa's society, which should be used as a means for tourism consumption. The South African tourism product is dominated by the game and bush experience. There is increasing interest in heritage tourism consumption, which South Africa has yet to capitalise on, especially in the historical townships, which were the centres of resistance against apartheid. This is an opportunity not exploited, to use heritage as a growth point, in these economically deprived areas. "Throughout the world, museums, art galleries, heritage sites, historical landmarks, archaeological sites and festivals have become major tourist attractions. Rather than just being peripheral or secondary attractions, arts and heritage are increasingly becoming major catalysts in the whole travelling experience" (Phaswana-Mafuya \& Haydam, 2005: 151). The visa regiment of a country has emerged as the most important determinant of the rate of international tourism to a destination. In the competitiveness of destinations, South Africa is further challenged by low levels of personal safety and security. Domestic tourism remains the bedrock of the tourism industry in South Africa, and it remains a function of the economic conditions of the country. According to Henama and Sifolo (2015), the tourism industry has benefited from an increase in Black South African tourists. The face of domestic tourism remains dominated by the White cohort of South Africans in terms of tourism consumption. The growth of tourism in South Africa will continue its upward trajectory as the state under President Cyril Ramaphosa has indicated that it will unlock the red tape impacting on tourism growth. South Africa must establish a Tourism Red Tape Initiative (TRTI), which would identify bottlenecks that limit tourism growth. The developmental benefits of tourism will increase, with the increase of tourist arrivals in South Africa.

\section{REFERENCES}

Aitken, C., \& Hall, M.C. (200o). Migrant and foreign skills and their relevance to the tourism industry. Tourism Geographies, Vol. 2 (1).

Alkhulayfi, B.A., Mohsin, A., \& Ramli, N. (2015). Halal tourism: Emerging opportunities. Tourism Management Perspectives, xxx: 10-20.

Apleni, L, Vallabh, D. \& Henama, U.S. (2017). Motivation for tourists' participation in religious tourism in Eastern Cape: A case study of Buffalo City, South Africa. African Journal of Hospitality, Tourism and Leisure, 6 (2); 1-14.

Astell, A.W. \& Peters, D.M. (2014). Schoenstatt's Shrine for the Pilgrim People of God. Claritas, 3 (2): 68-84.

Blichfeldt, B.S. (2007), The habit of holiday. Tourism Studies, 7 (3): 249-269.

Blickford-Smith, V. (2009). Creating a city of the tourist imagination: The case of Cape Town "The Fairest Cape of Them All". Urban Studies, 46 (9): 1763-1785.

Eid, R. \& Zamani-Farahani, H. (2015). Muslim world: A study of tourism \& pilgrimage OIC member states. Tourism Management Perspectives, xxx: 10-20.

Frisk, M.J. (2000). Contemporary pilgrimage-the Schoenstatt Experience. Marian Studies, 15 (5): 7-39.

Thornton, G. (2009), Report on the Economic Value of Tourism. Cape Town: GT.

Haines, G. (2017). Donald Trump's travel ban threatens to derail US tourism-while other nations stand to benefit. The Telegraph. Available at: http://www.telegraph.co.uk/travel/destinations/north-america/article.

Hamza, I.M., Chouhoud, R. \& Tantawi, P. (2012). Islamic tourism: Exploring perceptions \& possibilities in Egypt. African Journal of Business and Economic Research, 7 (1): 85-98.

Haydam, N. \& Phaswana-Mafuya, N. (2005). Tourists' expectations and perceptions of the Robben Island Museum-a world heritage site. Museum Management and Curatorship, 20 (2): 149-169. 
Henama, U.S. (2013). Attracting Indian Outbound Tourist to South Africa: A BRICS Perspective. India Quarterly: A Journal of International Affairs, 69 (3): 229-247.

Henama, U.S. \& Sifolo, P.P.S. (2015). Urbanisation and Migration as Factors Affecting Global Economic Development. IGI Global Publishers. International Migration through the Tourism Industry: Implications, Challenges and Contradictions in South Africa, 109-126.

Henama, U.S. \& Sifolo, P.P.S. (2017). Implications of climate change for tourism in Africa. GeoJournal of Tourism and Geosites, 2 (20): 191-198.

Henama, U.S. \& Sifolo, P.P.S. (2017a). Tourism Migration in South Africa: Current Dynamics, Immediate Challenges and Future Prospects. International Journal of Innovation in the Digital Economy, 8 (1): 47-55.

Henama, U.S. \& Sifolo, P.P.S. (2017b). Uber: The South Africa Experience. African Journal of Hospitality, Tourism and Leisure, 6 (2): 1-10.

Heystek, M. (2017). A modern-day Groot Trek. Moneyweb. Available at: https://www.moneyweb.co.za/ moneyweb-opinion/a-modern-day-groot-trek/.

Honkanen, A. \& Mustonen, P. (2007). Tourism consumption revisited-an empirical study of Finnish consumers. Research on Finish Society, 1: 43-58.

Hoogendoorn, G. \& Rogerson, C.M. (2015). Tourism geography in the global South: new South African perspectives. South African Geographical Journal, 92 (2): 101-110.

Hoogendoorn, G. \& Visser, G. (2015). A decade of second home tourism research in South Africa: research prospects for the developing world? South Africa Geographical Journal, 97 (2): 111-122.

Lubbe, G. (1987). Robben Island: The early years of Muslim resistance. Kronos: Southern African Histories, $12: 49-56$.

Peterson, T. (2017). Blood spattered on walls, pulpit of Cape Town mosque in second attack. Available at: http://www.news24.com/SothAfrica/News/blood-spattered/.

Rogerson, C.M. (2008). Shared growth in urban tourism: Evidence from South Africa, South Africa. Urban Forum, 19: 395-411.

Rogerson, C.M. (2014). Rethinking slum tourism: tourism in South Africa's rural slumlands. Bulletin of Geography: Socio-economic, 16: 19-34.

Rogerson, C.M. (2015). Restructuring the geography of domestic tourism in South Africa. Bulletin of Geography: Socio-economic, 29: 119-135.

Rogerson, C.M. (2017). Visiting friends and relatives travel matters for sub-Saharan Africa. African Journal of Hospitality, Tourism and Leisure, 6 (3): 1-10.

Shackley, M. (2001). Potential futures for Robben Island: shrine, museum or theme park? International Journal of Heritage Studies, 7 (4): 355-363.

Spencer, J.P., \& Steyn, J.N. (2011). South African tourism: A historical evaluation of macro tourism policies. African Journal of Physical, Health Education, Recreation and Dance, 17 (2), 178-200.

*** Department of Tourism. (2013). National Tourism Sector Strategy. Pretoria: GCIS.

*** Master Card-Crescent Ranking. (2016). Global Muslim Travel Index 2016. Available at: http:www.crescentrating.com.

*** News 24. (2014). Cape Town ranks as ideal holiday destination for Muslim tourism. Available at: http://www.news24.com/Travel/South-Africa/.

*** Property 24. (2017). Western Cape the "retirement mecca" of South Africa. Available at: https://www.property24.com/articles/western-cape/.

*** Reuters. (2017). Asia targets tourism, education boost from Trump travel ban. Available at: http://www.reuters.com/article/us-usa-trump-immigration-asia.

*** Schoenstatt. (2017). Cathcart. Available at: http://schoenstattsouthafrica.org.za/cathcart/.

*** South African History Online. (2017). Windvogelberg. Available at: http://www.history.org.za/dated-event/.

*** South African Tourism. (2017). Mosques and kramats. Available at: http://www.southafrica.net.

*** Statistics South Africa. (2017). The roads are less travelled. Available at: http://www.statssa.gov.za/?p=10398.

*** Statistics South Africa. (2018). Tourism Satellite Account. Available at: http://www.statssa.gov.za/?p=10398.

*** The Economist. (2017). How Donald Trump's immigration edict will affect American tourism. Available at: http://www.economist.com/blogs/gulliver/.

*** The Telegraph. (2017). Donald Trump's travel ban threatens to derail US tourism-while other nations stand to benefit. Available at: http://www.telegraph.co.za.

*** United Nations World Tourism Organisation. (2018). 2017 International Tourism Results: the highest in seven years. Available at: http:// http://media.unwto.org/press-release/2018-01-15/2017-internationaltourism-results-highest-seven-years.

*** World Travel and Tourism Council. (2017). Travel and Tourism Economic Impact 2017 South Africa. Available at: http://www.wttc.org/-/media/files/reports/economic-impact.../southafrica2017.pdf.

Submitted:

13.02.2018
Revised:

16.11.2018
Accepted and published online 19.11.2018 